\title{
Tributaries through time
}

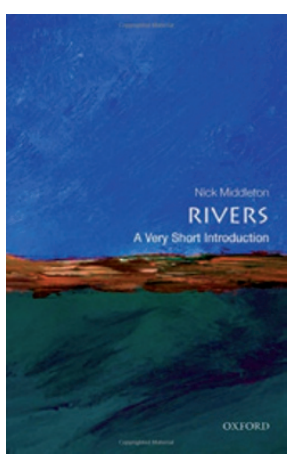

Rivers: A

Very Short

Introduction

Nick Middleton

RIVERS

Middleton

OXFORD

UNIVERSITY PRESS:

2012. 152PP. E7.99

$\mathrm{R}$ ivers wind, bend and stretch their way through almost every landscape on Earth, modifying the terrain as they go. But they also course their way through human history, culture and thought. In Rivers: A Very Short Introduction, geographer Nick Middleton explores the ways in which rivers have shaped not just the world we live in, but the also way we live in it.

Middleton begins by running the reader through the tremendous diversity of rivers, from the torrents that tumble through the humid tropics to the streams that trickle every now and then through the frozen deserts of Antarctica. Present-day puzzles and historic accounts of human endeavour, including an ancient Egyptian technique to measure the flow of the Nile, enliven an exploration of the difficulties in defining the physical properties of rivers, such as their source, length and flow.

This informative, if not entirely gripping, first chapter is followed by a fascinating foray into the role that rivers have played in cultures across the globe. For instance, Middleton delves into the underworld of Greek mythology, framed by the rivers of woe, lamentation, fire, hate and forgetfulness. Drinking water from the latter allows the good to forget their past lives and be reborn; drinking water from the river of hate would have rendered the Greek hero Achilles invincible, had it not been for his heel, which escaped immersion. The prominence of rivers in Judaic, Christian and Islamic accounts of paradise is also discussed. The inclusion of a sixteenth century illustration of the Christian paradise of Eden, depicting the four rivers that flow to different corners of the world, is a wonderful touch.
Middleton's exploration of the symbolic significance of floods in ancient and modern thought is equally captivating. He brings to the fore similarities between the JudaeoChristian story of the great flood, from which one man and his family escaped, and earlier tales from Babylonia, Sumeria and Assyria; in each case, floodwaters seem to cleanse and clear away sin, making way for new beginnings. Middleton shows how this symbolism continues to play out at a personal level today, for instance in the Christian practice of baptism. Middleton notes that floodwaters also mark the divide between the old and the new in Norse and Aboriginal cultures, and in written testimonies of several Maya groups.

Moving on to more practical matters, Middleton takes a look at the way in which rivers have shaped the settlement and spread of human societies. The banks of the rivers Nile, Tigris-Euphrates and Indus, for instance, served as settings for the first civilizations. That the management and manipulation of river water - and all that this entails - may have been a prerequisite for civilization is particularly thoughtprovoking. Middleton goes on to explain how rivers served as avenues for exploration in Britain, and paved the way for imperial expansion into Africa and Asia.

And if all this wasn't enough to convince the reader of the significance of rivers to human society, it seems that rivers powered the way to the modern industrial era. Middleton takes the reader on a 2,000-year tour of river-powered water mills, used to grind grain, cut rock and crush ore, among other things. The large-scale grain-grinding operations of ancient Roman civilizations are discussed in some depth, as are the mills of medieval Europe - the province of lords, city corporations, churches and monasteries. By the end of the Middle Ages, these water-powered machines could be found in streams and rivers across Europe, fuelling all manner of industries. By the start of the industrial revolution, the first water-powered textile factories had emerged.

No account of rivers and their role in society would be complete without an exploration of the role that rivers have played in the arts, a topic touched on towards the end of the book. Once a long list of river-inspired place names has been navigated, Middleton turns to the influence that rivers have had on a variety of cultural endeavours, including landscape painting, Russia's musical heritage, the evolution of the blues on the Mississippi Delta, and modernist literature. The chapter leaves the reader with a taste for river-based imagery and literary devices, but it is hard to do the subject justice in such a short book, and readers may end up wondering why their favourite book, poem or painting has been overlooked.

The book ends with an examination of the manifold ways in which humans have manipulated rivers over the ages. Middleton's account of the 2,000-year struggle to control the course and flow of China's Yellow River through the construction of dykes, dams and levées serves to illustrate the damage that rivers can do if left to their own devices. And his assessment of modern-day manipulation around 800,000 dams now dot the world's rivers, regulating an estimated $15 \%$ of all runoff from land - leaves the reader in no doubt of the extent of the engineering that has taken place, or, indeed, the unintended consequences; the reservoirs that accompany these dams have been shown to trigger earthquakes, alter local climate and even shift, albeit very slightly, the orbital characteristics of the Earth. When unintended influences, such as deforestation, urbanization, mining and climate change, are taken into account, some speculate that few, if any, rivers remain untouched by human disturbance.

It would be difficult to read this book and not come away with an appreciation of the all-pervading influence of rivers on human existence. For a long time, river waters and their inhabitants were afforded a certain degree of respect, and thus protection, in cultures across the world. This reverence is largely gone now. At a time when rivers seem stretched to capacity, this book serves as a refreshing reminder of the ways in which rivers have fostered, inspired, and frequently overturned, human societies across the ages.

\section{REVIEWED BY ANNA ARMSTRONG}

